\title{
Facts About Vitamin B12 ${ }^{1}$
}

\author{
Linda B. Bobroff ${ }^{2}$
}

\section{Why do we need vitamin B12?}

Vitamin B12 works with folate, another B vitamin, to make DNA, our body's genetic material. B12 is needed for proper formation of red blood cells and protection of nerve cells. It also helps keep blood levels of the amino acid homocysteine low. The balancing of homocysteine levels may help decrease the risk of heart disease in some people, although this research is ongoing. Everyone needs vitamin B12, but older adults and strict vegetarians (vegans) need to eat fortified foods or take a B12 supplement to get enough B12.

\section{What happens if we do not get enough vitamin B12?}

Vitamin B12 deficiency causes pernicious anemia, which affects blood and nerves. With this type of anemia, the body cannot make normal red blood cells that carry oxygen to all the cells in the body. Lack of oxygen makes people weak and tired. In addition, a severe vitamin B12 deficiency can cause nerve damage, leading to confusion, numbness in hands and feet, and loss of balance.

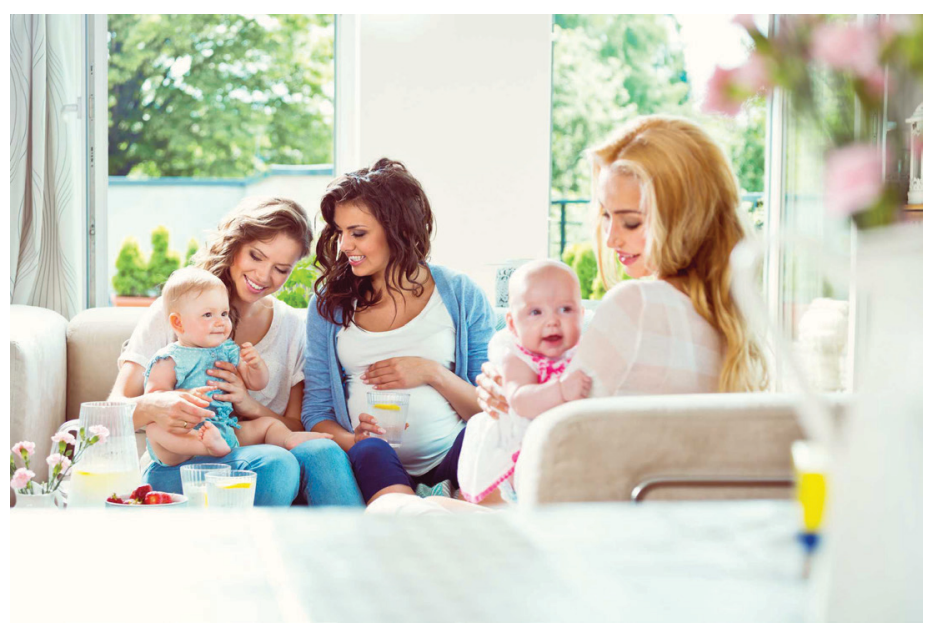

Figure 1. People of all ages need vitamin B12, but it is critical when new cells are being made, as in pregnancy and early childhood, or when you have a risk of poor absorption, such as in old age.

Credits: izusek/getty images

\section{How much vitamin B12 do we need?}

Table 1. Recommended daily intakes of vitamin B12.

\begin{tabular}{|l|c|}
\hline \multicolumn{1}{|c|}{ Life Stage } & Vitamin B12 (mcg/day) \\
\hline Adults, ages 19+ & 2.4 \\
\hline Pregnant women & 2.6 \\
\hline Breastfeeding women & 2.8 \\
\hline mcg = micrograms \\
Source: Otten, Hellwig, \& Meyers (2006) \\
\hline
\end{tabular}

1. This document is FCS8701, one of a series of the Department of Family, Youth and Community Sciences, UF/IFAS Extension. Original publication date June 2001. Revised January 2018. Visit the EDIS website at http://edis.ifas.ufl.edu.

2. Linda B. Bobroff, PhD, RDN, professor, Department of Family, Youth and Community Sciences; UF/IFAS Extension, Gainesville, FL 32611.

The Institute of Food and Agricultural Sciences (IFAS) is an Equal Opportunity Institution authorized to provide research, educational information and other services only to individuals and institutions that function with non-discrimination with respect to race, creed, color, religion, age, disability, sex, sexual orientation, marital status, national origin, political opinions or affiliations. For more information on obtaining other UF/IFAS Extension publications, contact your county's UF/IFAS Extension office. 


\section{How can we get enough vitamin}

\section{B12?}

Foods of animal origin, such as meat, fish, poultry, eggs, milk, and dairy foods, naturally contain vitamin B12. Fortified breads and cereals contain vitamin B12 in a form that is easily absorbed. Check the ingredient list on food labels to see if vitamin B12 has been added. Here is a sample ingredient list from a fortified cereal:

INGREDIENTS: Wheat bran with other parts of wheat, sugar, raisins, whole wheat, partially hydrogenated soybean oil, corn syrup, brown sugar syrup, nonfat milk, salt, honey, vitamin C (sodium ascorbate), vitamin B2 (riboflavin), vitamin B1 (thiamin mononitrate), folic acid, vitamin B12.

Table 2. Foods and the amount of vitamin B12 they contain.

\begin{tabular}{|l|c|}
\hline \multicolumn{1}{|c|}{ Food } & Vitamin B12 (mcg/serving) \\
\hline Oysters, cooked, 3 oz. & 30 \\
\hline $\begin{array}{l}\text { Beef, ground, extra lean, cooked, } \\
\text { 3 oz. }\end{array}$ & 1.8 \\
\hline Tuna, canned, 2 oz. & 1.6 \\
\hline Fortified cereal, 1 serving & 1.5 \\
\hline Yogurt, plain, 8 oz. & 1.3 \\
\hline Chicken, roasted, 3 oz. & 0.3 \\
\hline $\begin{array}{l}\text { mcg = micrograms } \\
\text { oz = ounces } \\
\text { Source: USDA ARS (n.d.) }\end{array}$ \\
\hline
\end{tabular}

\section{How should foods be prepared to retain vitamin $\mathrm{B} 12$ ?}

Vitamin B12 is not easily destroyed by cooking. This is good to know since the main food sources of vitamin B12, including meat, fish, and poultry, need to be well cooked. Other sources, like fortified cereals, may not need cooking.

\section{What about supplements?}

If you don't get enough vitamin B12 from foods, you can take an oral dietary supplement. Strict vegetarians (or vegans) who do not eat fortified cereals or fortified soy foods need to take vitamin B12 in a supplement. Also, adults over the age of 50 often do not absorb vitamin B12 very well due to decreased acidity in the stomach. If they don't get adequate B12 from fortified foods, they are advised to take a supplement.

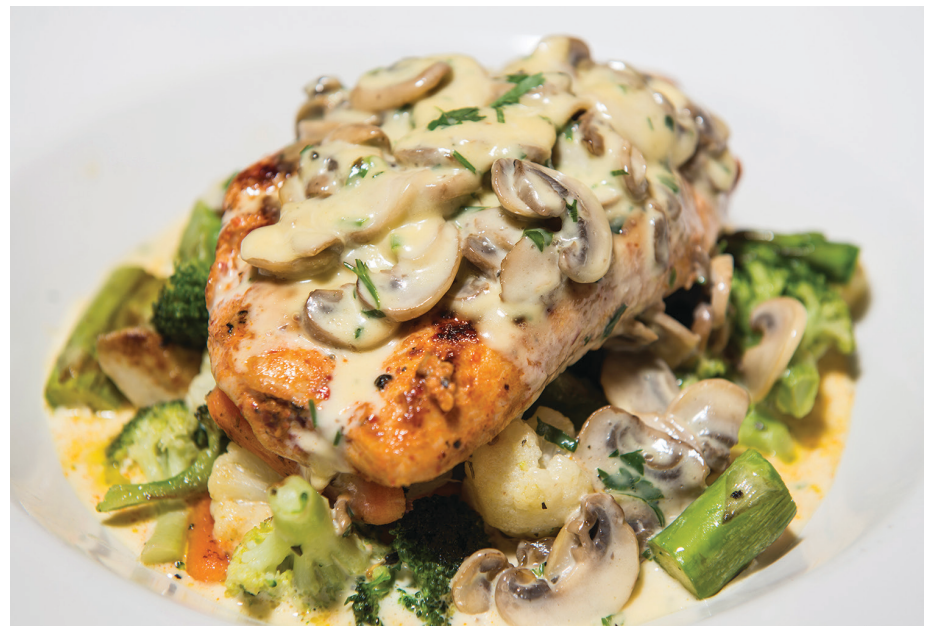

Figure 2. Vitamin B12 is naturally found in foods of animal origin. Vegans need to eat fortified foods or take a dietary supplement to get their B12.

Credits: photohaydar/istock/Getty Images Plus

\section{Where can I get more information?}

Your local UF/IFAS Extension Family and Consumer Sciences (FCS) agent may have more information and nutrition classes for you to attend. You can find your local UF/ IFAS Extension office at http://solutionsforyourlife.ufl.edu/ find-your-local-office/. A registered dietitian (RD or RDN) can also provide reliable information. Below are a few online sources that provide reliable nutrition information:

US National Library of Medicine: https://www.ncbi.nlm. nih.gov/pubmedhealth/topics/health/a/US

Office of Dietary Supplements/National Institutes of Health: http://ods.od.nih.gov

USDA: http://www.nutrition.gov

\section{References}

Otten, J. J., Hellwig, J. P., \& Meyers, L. D. (2006). Dietary Reference Intakes: The Essential Guide to Nutrient Requirements. Washington, D.C.: The National Academies Press.

USDA ARS. (n.d.). USDA Food Composition Databases. Accessed on January 26, 2018. https://ndb.nal.usda.gov/ $\mathrm{ndb} /$ search/list 